\title{
KÖZÖSSÉGÉPÍTÉS TELEPÜLÉSI DIMENZIÓI ${ }^{1}$ SETTLEMENTS DIMENSONS OF COMMUNITY DEVELOPMENT
}

\author{
Tóth Tamás
}

\author{
egyetemi tanár \\ Szent István Egyetem, Gazdaság és Társadalomtudományi Kar \\ E-mail: toth.tamas.argi@gtk.szie.hu
}

\section{Összefoglalás}

A cikk számba veszi és rendszerezi a sikeres közösségépítést befolyásoló és támogató folyamatot, eszközöket, módszereket, teszi ezt azért, mert ugyan az Európai Unió és tagállamainak tervezési gyakorlatában hivatalosan is elöírják a közösségek bevonását, de e normatívan nehezen szabályozható tématerület szükszavú elöírásainak betartása azonban még nem jelenti azt, hogy minden az elöírásoknak megfelelő tervezési folyamat valóban közösségi tervezésnek minősülne. A közösségi tervezés rendszerét, annak fontosságát számos szerző tanulmánya igazolja, de leginkább a valós életben megvalósuló és müködő projektek tapasztalatai jelenthetnek megbízható alapot a közösségi tervezési modelleinek. Közösségi tervezésnek nevezzük, ha a tervezési folyamatba már annak egészen korai szakaszában is ténylegesen bevonják az érintetteket. A közszféra tervezési tevékenységeiben egyre inkább elvárássá vált a közösség bevonása, melyet már különböző nemzeti jogszabályok, tervezési módszertanok, sőt nemzetközi egyezmények is megkövetelnek. Ezért nem véletlen, hogy a tanulmány ezt a témakört vizsgálja.

\begin{abstract}
The article investigates and systematises the process, tools, and methods that influence and support successful community building. Although involving communities in the planning processes is obligatory for the EU member states, complying with the generally formulated rules of this topic, which is difficult to regulate to begin with, does not mean that a planning process carried out according to rules would actually become community planning in practice. The system of community planning has been investigated and its importance has been proven by many academics, but the most solid basis for community planning models comes from the experience of projects carried out by actual communities. Community planning is a process in which the stakeholders are involved from the very early stages. This kind of involvement in the planning process of the public authorities is increasingly required by national law, planning methodologies and international treaties. For this very reason present study deals with this highly important topic.
\end{abstract}

Kulcsszavak: önkormányzat, közösségépítés, településfejlesztés

JEL besorolás: R11, H1, H75, P25

LCC: JS39 8500, JS141 163

\section{Bevezetés}

A közösségi tervezés területfejlesztési jelentősége kézenfekvő, a tervezés ún. „társadalmasításában” sokkal nagyobb hatást képes elérni, mint a hagyományos, tervváltozatok

${ }^{1}$ „A mű a KÖFOP-2.1.2-VEKOP-15-2016-00001 azonosítószámú, „A jó kormányzást megalapozó közszolgálatfejlesztés" elnevezésü kiemelt projekt keretében, a Nemzeti Közszolgálati Egyetem és a Szent István Egyetem együttmüködésével készült." 
egyeztetésén alapuló módszer. A terv, és az annak nyomán bekövetkező fejlesztések társadalmi elfogadottsága is sokkal nagyobb.

Sokan gondolják már szerencsére azt, hogy a sikeres és jól működő település közügy és az is általánosan elfogadható tény, hogy ehhez jól müködő, az erőforrásokat bevonzó és hatékonyan felhasználó helyi gazdaságra van szükség. A helyi gazdaság biztonságos, hosszútávon fenntartható sikeres működtetése mindannyiunk, akarom mondai a helyi közösség egyik legfontosabb ügye. Ezen kérdések vizsgálata már évek óta foglalkoztatja a Szent István Egyetem Gazdaság- és Társadalomtudományi Karán müködő tudományos mühely kutatóit, mely munkaközösség a Nemzeti Közszolgálati Egyetem kutatóival karöltve pályázati keretben valósítja meg elképzeléseit. A pályázat jelentősége, hogy állam-centrikus megközelítéssel hozzájárul a biztonság-kultúra fejlesztéséhez, az állam és polgárok biztonság-szemléletének emeléséhez, a vidék versenyképességének növeléséhez.

Sokan értenek egyet a Szilágyi-Boldizsár szerzőpáros helyes megfogalmazásával: "A vidékbiztonsági tudatosság kialakítása eredményeként a polgárok nemcsak, hogy felismerik, értékelik és megértik, hanem kihasználják a vidék és a biztonsági környezet lehetőségeit, de aktív módon befolyásolhatják is azt. Cselekvőképes, tudatos, biztonságtudatos állampolgárként, a törvényi keretek között maguk is hozzájárulhatnak a komplex biztonsághoz mikro- és makroszinten is. A vidékbiztonság valamennyi dimenziójának felismerése és egymással folyamatos kölcsönhatásban lévő dinamikus egységként kezelése új típusú szemléletmódot, felelősségérzetet és gazdasági lehetőséget is hordoz magában (SzilágyiBoldizsár, 2016).

A kutatás kiinduló pontjaként meghatározásra kerültek a vidékbiztonság különböző pillérei.

- POLITIKAI-KORMÁNYZATI

- FIZIKAI

- $G A Z D A S A ́ G I$

- SZOCIÁLIS-TÁRSADALMI

- KÖRNYEZETI-KÖRNYEZETVÉDELMI

- ÉLELMISZER-ÉLELMEZÉSI

- INFRASTRUKTÚRA

- FENNTARTHATÓSÁG ÉS MEGÚJULÁS

- VIDÉKBIZTONSÁGI ÖNGONDOSKODÁS (Szilágyi-Boldizsár, 2016)

Az előzőleg említett megfogalmazások rendszerezik mindazokat a tényezőcsoportokat, amelyek meghatározzák a vidékbiztonság egészét. Egyfajta rendszerszemléleti megközelítéssel egy olyan ismerethalmazt tárnak elénk, amelyek átfogóan tanúsítják, hogy mely tényezöcsoportokat szükséges a kérdéskör elemzésekor figyelembe venni. Természetesen a jelen tanulmányhoz a gazdasági pillér és a szociális- és társadalmi pillér az, ami közvetlenül kapcsolódik. Akkor tudunk egy jól müködő helyi gazdaságot, vagy sikeres települést kialakítani, hogyha minden egyes tényezőcsoportban megfelelö feltételeket tudunk biztosítani, mivel ezen tényezőcsoportok - nevezetesen pillérek - mindegyike komoly hatást gyakorol a másikra, vagy a többire, ezáltal egyik sem megkerülhető.

Arról sem feledkezhetünk meg, amit Oláh (2017) dolgozatában pontosan megfogalmaz, hogy minden település egyedi, "...minden település más és más karakter. Mindegyiknek megvan a maga jellegzetessége, múltja, jelene, mely a jövőjét nagyban meghatározza. Így megfelelő és egységes településcsoportok kialakítása nem lehetséges anélkül, hogy tompítanánk az egyedi jellemvonásokat. Ahhoz tehát, hogy akár csak néhány tényezö mentén következtetéseket 
tudjunk levonni egy kisebb településcsoportra, ismernünk kell a csoportba tartozó minden falut, és fel kell ismernünk a köztük (és más csoportok tagjai között) meghúzódó látható vagy láthatatlan, közvetlen vagy közvetett kapcsolatokat és folyamatokat”'(Oláh, 2017).

Erről nem feledkezhetünk meg akkor sem, amikor egy vagy több települést vizsgálunk, és próbáljuk meghatározni annak fontos elemeit, mivel egy társadalom rendszerét vizsgálva a jólét, avagy életminőség javítása domináns célként határozható meg. Ennek megfelelően egy tervezési rendszer vizsgálatakor, az elméleti rendszerek áttekintésekor fontos tényező a pontos cél meghatározása. A területfejlesztés rendszerében a fejlődés négy terület köré koncentrálódik, úgymint:

- gazdasági (hatékony cégek, alacsony munkanélküliség, nagy jövedelmek, fogyasztó, stb.),

- politikai (demokratikus közélet, jó légkörü városirányítás, közvetlen érdekérvényesítés, stb.),

- kulturális (gazdag kulturális élet, színvonalas oktatás, változatos rendezvények, sportés tudományos élet, stb.),

- környezeti, ökológiai (természeti értékek állapota, védelme, ökológiai fejlesztések, stb.) (Piskóti, 2000).

Ezen négy terület egysége, összhangja biztosíthatja, hogy megfelelő gazdasági életszínvonalon, sikeres üzleti müködés mellett, jó közéleti, demokratikus, polgárbarát városmüködés, gazdag tudományos, müvészeti, sport kínálat, tevékenység jelenjen meg egy értékeiben megőrzött, védett környezet, ökológiai tudatosság mellett.

Számos alkalommal sokan kimondtuk már, hogy a területi politika, illetve a területfejlesztési politika célja a társadalom és a gazdaság térbeli jellegzetességeinek elemzése, ezen folyamatok mélyreható vizsgálatát teszi lehetővé a területi tőke. „A területi tőke tehát olyan adottságok összessége, amelyek hely- vagy térség specifikusak, $\mathrm{s}$ egyben arra orientálják a fejlesztéspolitikát, hogy annak fókuszába a lokális értékek kerüljenek, azok folyamatos megújítására koncentráljanak.” (Rechnitzer-Smahó, 2011, Káposzta et al., 2015, Nagyné 2013, Goda-Kassai, 2011, Horváth, 2013) Az egyedi értéket jelentheti a közösség társadalmi aktivitása, helyi gazdasága, infrastruktúrája, adódhat környezeti adottságaiból, valamint a külső anyagi és szellemi javak nyújtotta lehetőségek befogadásának képességéböl (Goda-Tóth, 2013, Goda et al, 2013). A települések egyedi értékei igen fontosak, befolyásolják gazdasági sikereik és lakosaik megfelelö életszínvonalának biztosítását (Káposzta, 2001; Ritter et al., 2013).

Mint ahogy arra a Bakos-Bálint (2015) szerzőpáros rámutatott, „,egy közösség, település, térség megfelelö müködéséhez a testileg és mentálisan egészséges ember az egyik legfontosabb erőforrás, hiszen biztosítja a munkaerőt, a népesség fennmaradását, a képességek, hagyományok továbbörökítését, az intézmények fenntartását, a jövedelem megtermelését, a közösségszervező erőt” (Bakos-Bálint, 2015.).

Az egyes területeken megfogalmazott célok gyakorta mondanak ellent egymásnak, pl. egy gazdasági növekedés nem mindig szolgálja közvetlenül az ökológiai célokat (Káposzta et al., 2012). Ilyenkor egy olyan kompromisszum elérése kívánatos, mely az „összelégedetlenség” minimalizálását jelenti. A jólét, mint végső cél elérése számos elemből tevődik össze, melyeket gyakran találunk meg az egyes régiók, települések terveiben. A vonzerő, attraktivitás, versenyképesség növelése eszköz-jellegü, közvetlen célokként jelennek meg (Kollár et al., 2009). Természetesen a négy cél mindegyike további részcélokká bontható, s így alakul ki az a többszintü (stratégiai és taktikai) célhierarchia, melynek komplexitása, belső összefüggésrendszere leképezi a régió és város, településmarketingbeli aktivitásait. Az egyes 
tartalmi területeken a célok kibontása három cselekvési síkon jeleníthető meg, azaz megfogalmazódnak:

- fejlesztési, növekedési, új megoldásokat felvonultató, sokszor innovatív törekvések,

- a meglévő intézmények, szervezetek hatékonyabb müködtetésére szolgáló javaslatok, célok,

- illetve az ezeket kísérő vagy éppen önálló kommunikációs, promóciós törekvések.

Mindezen célhierarchia részeit átképezve a területfejlesztés rendszerére megállapítható, hogy a területfejlesztés egy rendkívül komplex tevékenység, ebből eredően a tervezési eljárások és módszerek alkalmazásának és megválasztásának elengedhetetlen feltétele az integrált megközelítés. Olyan eljárások, és módszerek alkalmazását igényli tehát a vidékfejlesztés tervezése, amelyek kezelni képesek a vidékfejlesztés sajátosságait, és érvényesíthető az integrált megközelítés (Molnár, 2013).

Mint ahogy azt Faragó (2009) is meghatározta ”a tervezés „kísérletezésen” alapuló ciklikus tanulási, racionalizálási folyamat, a sikerorientált intencionális társadalmi cselekvés egyik jól strukturált instrumentális módja, az (ex ante) irányítás explicit eszköze. A tervező a történetileg szituált jelenhez egzisztenciálisan kötődő, érvelési és stratégiai kompetenciákkal rendelkező kommunikatív individuum. A terv a szándékolt cselekvések konkrét pillanatban rögzített (elörevetített) képe, a normákkal átszőtt társadalmi cselekvés objektivációja, elfogadása pedig kötelezettségvállalás. A tárgyiasulás nem elsősorban a megvalósítás érdekében szükséges, hanem az átláthatóságot, a véleményezhetőséget, a partnerség elvének teljesíthetőségét, a számonkérhetőséget szolgálja. Mindezek biztosítása érdekében használatát a társadalmi normák és azokat szakaszosan követő jogszabályok szabályozzák. Információkat tartalmazó, üzenetet közvetítő, mértéket adó kommunikációs eszköz. A terveket maradéktalanul nem megalapozható és igazolható hipotézisként foghatjuk fel, amelyeket időről időre felül kell vizsgálni” (Faragó, 2009).

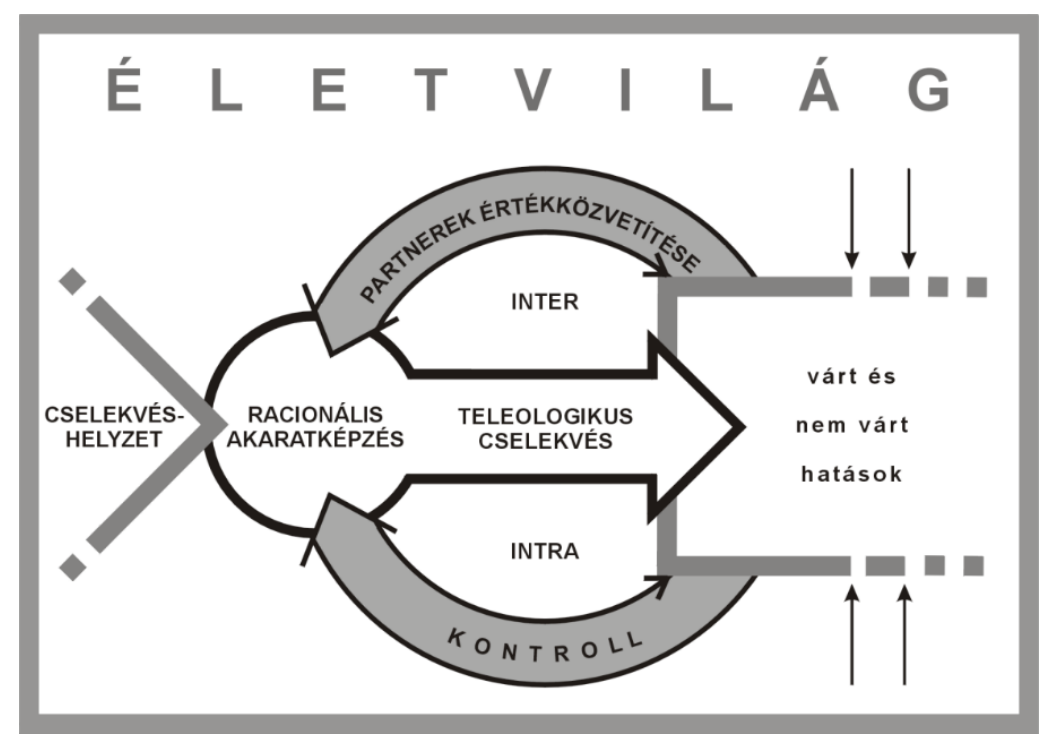

Forrás: (Faragó, 2009)

1. ábra: A tervezés kettős tanulási és ellenőrzési köre

Fontos megteremtenünk azokat a körülményeket melyek segítik a tervezési folyamatot. A partnerség a sikeres tervezés és megvalósítás egyik feltétele, épp ezért a programok jobb megvalósításához és minőségéhez vezet, mivel:

- javul a kommunikáció, a helyi tudás és a döntéshozatali képesség;

- javul az együttmüködés a szervezetek között, beleértve az erőfeszítések növekedésének 
elkerülését;

- fokozott képességet jelent, amely felhasználja a partnerségeknek köszönhető alapokat, ami a források hatékonyabb kezeléséhez vezet;

- más programokra is kedvező hatással lehet stb.

Általában igaz, hogy egy projekt megvalósulását nehezíti, ha sajnálják az időt az érdekeltek csoportjainak meghatározására, elvárásaik és a projektre gyakorolt egyéni hatások feltérképezésére és összehangolására, az igények és elvárások változásának figyelemmel kísérésére és a projekt kommunikációs stratégiájának megtervezésére. Az új, partnerségre és helyi forrásokra épülő modellben alapvetően átértékelődik a helyi, és a nem közhatalmi, gazdasági és társadalmi érdekcsoportok szerepe. A regionális politika regionalizálásának is nevezett trend (Bruder, W.-Ellwein, T. 1979, Kruse, H. 1990) szerint a térségi problémák megoldásában elsődlegesen a helyi-regionális döntéshozóknak aktivitására, a politikai akaratképzés regionalizálására van szükség. A felsőbb, központi szintek feladata a szubszidiárius rásegítő támogatás, a regionális politika makro-összefüggéseinek a szabályozása, az ágazati politikákkal való összehangolása, illetve az ágazati politikák területi dimenzióinak erősítése. A helyi szereplők feladata már nem egyszerüen az érdekvédelem, hanem a helyi programok kidolgozása és a végrehajtás garanciáinak megteremtése a fejlődésben érdekelt valamennyi csoporttal, szervezettel közösen. E megváltozott feladathoz a tervező közigazgatás konszenzusképző és konfliktusfeloldó kapacitását jelentősen növelni kellett, mégpedig úgy, hogy mind a gazdasági piaci szereplők, mind pedig a területpolitika „áldozatai”, a munkavállalók és a lakóhelyi közösségek érdekképviseleti lehetőséghez jussanak. (Káposzta-Nagy, 2003)

A területfejlesztés egyik alapvető jellemzője a „külső” szakértői tervezés, amely sok hiányossággal bír, valamint eredményessége is kifogásolható. A probléma alapját az képezi, hogy a tervező az általa fontosnak ítélt társadalmi szereplőket keresi meg és a tőlük begyüjtött információ egyedül a tervező kezében összpontosul. Az így kapott információhalmazra alapozva magát a döntést is a tervező hozza meg. (2. ábra)

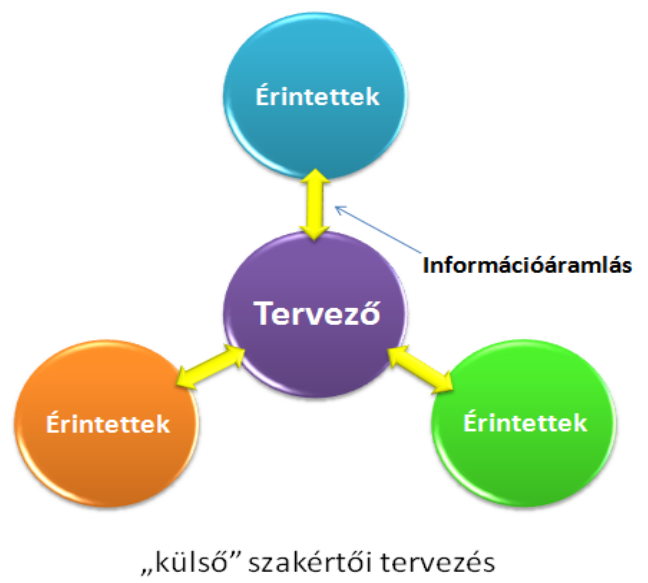

\section{2. ábra: Külső szakértői tervezés sémája}

Forrás: (Tóth-Oláh, 2012)

A „belső” más néven közösségi tervezés nem egy tágabban értelmezett szakértői tervezés. (3. ábra) Kulcseleme a helyi szereplők aktivizálása, a jövőkép közös kialakítása. A közösségi tervezés alkalmazásakor az érintettek már a tervezés legelején aktívan részt vesznek a munkában. A helyzetfeltárás alkalmával lehetőségük van megismerni egymást, megosztani egymással az elképzeléseiket és alapvető értékeiket, melyeket meg szeretnének valóstani. 
Tapasztalható, hogy a szakértői tervezéshez képest sokkal magasabb a résztvevök elkötelezettsége, és aktívan részt vesznek a munkában. Az együttgondolkodás során kapott terv társadalmasítása meglehetősen könnyü, hiszen az a közösség által elfogadott konszenzussal jött létre (Szaló, 2010).

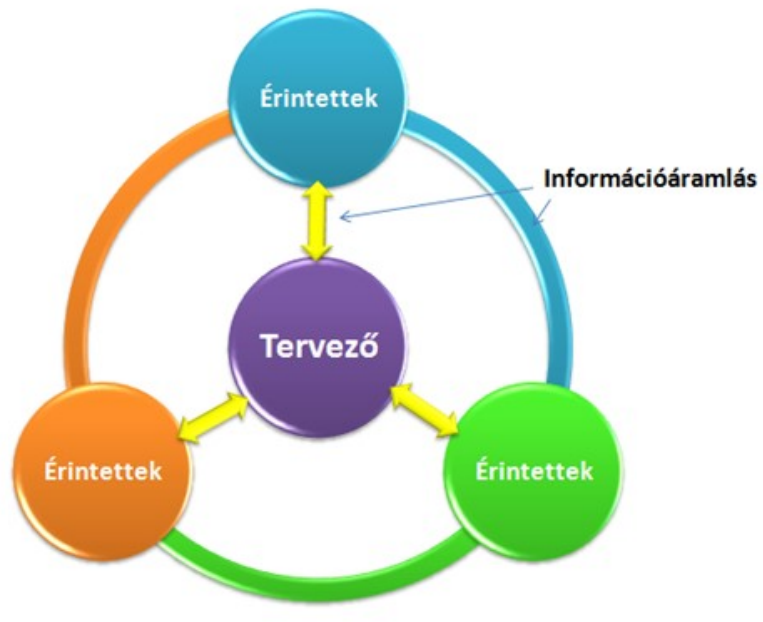

„belső” közösségi tervezés

\section{3. ábra: Belső szakértői tervezés sémája}

Forrás: (Tóth-Oláh, 2012)

A közösség bevonásának vannak bizonyos kritériumai, melyek számbavételét célszerü a tervezés előtt elvégezni valamint az esetleges kockázatokat is fel kell mérni. Tisztázni kell a fejlesztés indíttatását, milyen motivációs tényezők állnak rendelkezésünkre a tervezés során. A tervezés sok fáradozást igényel az összes résztvevőtől. A sok idő és energia befektetésen túl meg kell küzdeni azzal a pszichés nyomással, amely az emberi gyengeségek és konfliktusokkal történő szembesüléskor keletkezik. Azok a tervezők testesíthetik meg a közösségi tervezés biztos motivációs hátterét, akik kellő elszántságuk, munkájuk és meggyőző erejük által a lakosság érdeklődését fel tudják kelteni és ösztönözni tudják az érintetteket a munkájuk eredményes elvégzésében.

\section{Anyag és módszer}

A tanulmány alapvetően a témához szorosan kapcsolódó irodalmak feldolgozásával próbál megfelelö elméleti hátteret gyüjteni ahhoz, hogy egy átgondolt tervezési folyamatot körvonalazzon, mely a már felhalmozott gyakorlati tapasztalatokból is felhasználja azokat az ismereteket melyek az elmúlt évtizedekben halmozódtak fel az intézetünkben müködő kutató műhelyek tevékenységének eredményeként. Ez a két jól elkülöníthető forrás adja munkám alap építö köveit.

Másrészről kutatótársaimmal már évek óta vizsgálunk különböző közösségfejlesztési, tervezési folyamatokat és azok meghatározó elemeit. (Gerencsér-Tóth, 2017)

\section{Eredmények}

Több írásmüben jómagam is megfogalmaztam már, hogy fejlődés, megfelelő és átgondolt tervezés nélkül nehezen valósítható meg, megkockáztatom csak a jószerencsének köszönhető. Ezért szükséges a folyamat minden elemét azonosítani és rendszerbe szervezni, melyre már többször tettem kísérletet, jelen munkában a közösség bevonásának a jelentőségét szeretném minél jobban hangsúlyozni és ennek tervezési motívumait kiemelni. A tervezés általános 
értelmezése - nevezetesen, hogy az valamilyen kívánatosnak tartott jövőbeli állapot felvázolását, valamint az annak elérését lehetővé tevő út (utak) és feltételek (eszközök) meghatározását jelenti - ma is elfogadható.

A tervezési folyamat lépéseihez használható főbb eszközök tárháza talán kimeríthetetlen és folyamatosan bővülö. A következőkben ezt a folyamatot nézzük meg részletesen.

Strukturált közösségi térségi tervezés ( $3 * 3$ lépés):

Egy társadalmi-gazdasági program multiszektorális és sokcélú. Feladata olyan gazdasági, illetve közösségi átalakítások végrehajtása, amelyek az egész térségre hatással vannak. Ennek elérése céljából olyan integrált stratégiát szükséges használni, amely különböző csoportokra (közösségek, vállalkozások, alkalmazottak, munkanélküliek, stb.) irányul. Átfogó hatást kell elérni a különféle célokra irányuló sokféle speciális hatás megfelelő kombinációja révén. Épp ezért a területi tervezés célját (a lehető legtöbb jót a lehető legtöbb ember számára) csak jól strukturált tervezési folyamaton keresztül, a megfelelő módszerek használatával lehetséges elérni illetve közelíteni, mivel utópisztikus ötlet azt állítani, hogy az elérhető, de törekednünk kell rá.

A térségi tervezés klasszikusan három fő szakaszból áll, Helyzetfeltárás, Stratégia kialakítása, Operatív programozás, ezen tervezési szakaszok természetesen több lépésből állnak össze, melyet az alábbiakban a közösségi tervezés aspektusából fejtek ki:

\section{A területfejlesztés szereplöinek elvárásainak feltérképezése /I. lépés/}

Ahhoz, hogy adott területi egységen tudjuk segíteni az érintettek boldogulását, szükséges, hogy ismerjük azokat az igényeket, szükségleteket, melyeket azok meg tudnak, vagy esetleg meg sem tudnak fogalmazni, vagy már megfogalmaztak. Ide tartoznak a térségben élök, idelátogatók elvárásai, mivel nem csak a közvetlen helyi igényekre szükséges odafigyelni, fontos lehet az időleges elvárásoknak való megfelelés, mind a turizmus gazdaságélénkítő hatásai, mind az időszakos zsúfoltságokat is kezelni tudó élhető környezet biztosítása érdekében.

A közösségfejlesztő feladata a tervezés kezdetén a helyi szereplők megszólítása. A fejlődés tulajdonképpen egy mozgásokkal teli közegben valósul meg. Össze kell gyüjtenünk egy adott területen a cselekvő tényezőket, a köz- és magánintézmények, a helyi közösségek, egyesületek, a közigazgatás képviselőit, stb. A helyi intézmények képviselőit tulajdonképpen egy partnerkapcsolatba kell összefogni, vagyis lényegében szövetkezéssé kell alakítani, mégpedig úgy, hogy felvetjük a kérdést: mindannyian ezen a településen, ebben a térségben lakunk. Nem gondolják úgy, hogy szükséges lenne összeállnunk és közösen gondolkodnunk? (VargaVercseg, 1998)

Az helyi lakosságot aktivizáló módszerek körébe tartoznak a következők:

- A helyi jelentős személyiségekkel, véleményformálókkal készített egyéni interjúk;

- az ún. nyilvános beszélgetések;

- $\quad \mathrm{a}$, ,jövőmühely" módszere;

- a település humán-, természeti- és gazdasági erőforrásait felmérö és aktivizáló közösségi felmérés

- „Tankatalógus”: a helyi emberi erőforrások - tudás, tapasztalat és tehetségek - feltárása és megjelentetése helyi orgánumban: kalendárium, évkönyv

- helyi önszervező-köri mozgalmak: településszépítő, környezetvédő, természetvédő, 
virágosítási mozgalmak

- párbeszéd körök (Varga-Vercseg, 1998)

\section{A környezet értékelése /II. lépés/}

Ezt a periódust hívjuk társadalmi-gazdasági kórmeghatározásnak. Ez a diagnózis három alapvető pilléren nyugszik: a lakosság, a gazdaság és a fejlesztési rendszer feltérképezésén, elemzésén. Amikor a mérleget megvonjuk, az adatok közötti kapcsolatokat is ki kell alakítanunk.

A vizsgálat az alábbi elemek részletes feltérképezésére irányul:

- Globális környezet értékelése, tendenciák felvázolása

- Nemzetgazdasági környezet értékelése, tendenciák felvázolása

- Területfejlesztés eszköz- és intézményrendszerének értékelése

- Térséget érintő fejlesztési koncepciók értékelése

Látható, hogy a környezet értékelése során négy különböző dimenzió mentén kell a vizsgálatainkat elvégezni, természetesen nem mindegy, hogy mely területi szinten tervezünk. A szinttől függően az egyes dimenziók jelentősége változhat, de ez általános szabályként is megfogalmazható a tervezési folyamat lépéseire vonatkozóan. A környezeti dimenziók és azok tartalmi elemeinek vizsgálatakor a múlt és a jelen vizsgálatával szeretnénk a jövő tendenciáit meghatározni, mivel a jövőbeni eseményekre, bekövetkező változásokra illeszkedő és megvalósítható terveket szándékozunk kidolgozni.

Gyakran használt módszerek: regionális veszteségtérkép, SWOT analizis, szélső értékek összevetésén alapuló mutatók, szórás típusú jelzöszámok, közúthálózat megfelelőségi mutató, komplex közlekedési hálózati mutató (TRANS), pontozásos módszerek, matematikai-statisztikai módszerek: regresszió elemzés, faktoranalizis, fökomponens analizis, klaszteranalizis, Fuzzy logika, térképi ábrázolás és térinformatikai módszerek, regionális modellek, ECO-line modell, Socio-line modell, LINE modell, input-output megközelítés, társadalmi elszámolási mátrix.

A térség jövőjét nagyban befolyásolhatják a vonatkozó fejlesztési koncepciók, ezért megkerülhetetlen a tartalmi ismeretük, már csak a fejlesztésekhez kapcsolódó hatékony forrásallokáció (köznapiasan fogalmazva pénzszerzés) okán is. Tehát meg kell vizsgálnunk, melyek azok a célok, elképzelések, melyek „felsőbb” területi szinten fogalmazódnak meg, így preferálhatók vagy kötelezö érvényüek számunkra.

Az igények értelmezése, a szükebb tágabb környezet vizsgálata után meg kell néznünk azt is, hogy milyenek a térség adottságai, ezen adottságok mind mennyiségükben mind minőségükben hogyan befolyásolják a terület müködését.

\section{A térség adottságainak és az igények értékelése és dinamikus vizsgálata / III. lépés/}

A harmadik periódus a közösség véleményének, késztetéseinek, cselekvési potenciáljának feltárása, amely nélkül egy közösség hátrányos helyzetben érezheti magát a konzultációkon, kivált fontos kérdésekben. A hivataloknak konzultálniuk kell a közösséggel pl. földhasználati, tervezési és közlekedési ügyekben, az egészségügyi ellátás kérdésében és sok más területen. Egy jól müködő és a megfelelő válaszokat produkáló felmérés segítségével pl. lehetővé válik a megfelelő helyi politika és a mindenkit kielégítő szolgáltatási rendszer kialakítása. Ezért a legkisebb közösségeknek is érdemes összefogniuk és kialakítaniuk saját közösségi politikájukat. Belátható, hogy az erőforrások sajátosságai, milyenségük, mennyiségük, 
színvonaluk, állapotuk, stb. a kiinduló pontjai és meghatározó faktorai a jövőkép felvázolásának, a kapcsolódó programok, stratégiák irányultságának, stb. Az egyes erőforrásokhoz tartozó elemzésnek - a teljesség igénye nélkül - az alábbi területekre kell kiterjednie:

- Társadalmi környezet, humán erőforrások vizsgálata,

- Gazdasági bázis értékelése,

- Környezet adottságainak vizsgálata,

- Infrastruktúra, a térség intézményi ellátottsága elemzése,

- Településhálózat, kohéziós kapcsolatok értékelése

Gyakran használt módszerek: regionális veszteségtérkép, szélső értékek összevetésén alapuló mutatók, szórás típusú jelzöszámok, közúthálózat megfelelöségi mutató, komplex közlekedési hálózati mutató (TRANS), Hoover index, pontozásos módszerek, regresszió elemzés, fókomponens analízis, klaszteranalizis. Fuzzy logika, lineáris programozás, térképi ábrázolás és térinformatikai módszerek, társadalmi elszámolási mátrix.

Az előzőekben érintett erőforrások, ill. szempontok elemzésének eredményeként egyrészt meg kell tudni fogalmazni és minősíteni a kialakult tényállapotokat, másrészt egyértelmüen fel kell ismerni, és arányosítani kell a problémákat, a problémák közötti hatásokat és összefüggéseket, valamint egyértelmüen meg kell határozni, hogy kik a probléma érintettjei, ill. célcsoportjai.

Érintettnek tekintünk minden olyan személyt, csoportot, intézményt, vállalkozást, melynek bármilyen - közvetlen, vagy közvetett - kapcsolata van a tényleges helyzettel, illetve a jövőt illetően megvalósítandó program céljaival, hatásaival:

- Külső környezeti feltételek SWOT elemzése

- A térségi adottságok SWOT elemzése

- A területfejlesztés szereplőinek elvárásainak és a lehetőségek egyeztetése (stakeholder elemzés)

Ha visszaemlékezünk az első lépésre, ahol feltérképeztük az igényeket, valamint az előző lépésben az adottságokra, úgy mostanra elegendő ismerettel rendelkezünk ahhoz, hogy megnézzük, az elvárások, igények milyen mértékü kielégítését teszik lehetővé a terület adottságai.

A véleményalkotás során figyelnünk kell arra, hogy dinamikus vizsgálatot végezzünk, tehát a részelemek, tényezők egymást befolyásoló hatásait is vegyük figyelembe. Jó esélyt nyújt erre a SWOT elemzés, mely strukturált csoportmódszerként nagyságrendileg eredményesebb, mintha egyénileg végeznénk. (Meggyőződésünk szerint mind a területi tervezés, mind a projekttervezés csapatmunkaként végezhető csak el.)

\section{Stratégiai célok kitüzése /IV. lépés/}

A negyedik fázis a feladatok közös rangsorolása - a tervezés. Készítsünk táblázatot a feladatok sorrendiségének és a felelősök meghatározásának céljából. A táblázat rovata azoknak az itt és most közösen meghatározandó felelösöknek a köre is, akiknek a kompetenciájába a csoport szerint az adott ügy beletartozik: helyi önkormányzat, helyi lakosok, helyi közösségek, orgánumok, szakértők, szakmai és érdekképviseleti szervek, munkaügyi központ, központi kormányzat, stb. Lehet a táblázatnak egy „hogyan?” rovata is, amelybe a megvalósítás módozatai írandók, pl. 1. lépés: képzés, 2. lépés: a szervezet (pl. szövetkezet) megalakítása, stb. 
Helyi nyilvánosságot szervező módszerek

- Az egyéni tájékozódási lehetőségek fejlesztése: a lakosság által tudott és elérhető félfogadásai; a különféle tanácsadások rendszere (egészségügyi, jogi, vállalkozási, utazási, gyermeknevelési, továbbtanulási, gazdálkodási stb.); a településeken belül gyüjtő tájékoztatóhelyek kialakítása és a lakosság számára hozzáférhetővé tétele (polgármester hivatal, falugondnokok, gazdajegyzők, lelkészek, könyvtár, müvelődési ház, helytörténeti gyüjtemény, egyesületi székházak).

- A helyi tájékoztatási feltételek javitása technikai eszközök közvetítésével: kalendárium, falukönyv, rendszeresen megjelenő helyi újság, idegenforgalmi kiadványok, helyi képeslap, helytörténeti kiadvány, helyi TV, rádió.

- Csoportos jellegü fórumok: az a módszer, amellyel a helyi nyilvánosság a leghatékonyabban befolyásolható, mert a helyi közösségek és kölcsönhatásuk, partnerkapcsolataik, együttmüködésük, stb., vagyis jelenlétük ereje az, amely meghatározza a polgárok és intézményeik közötti oda-vissza kommunikációt. (VargaVercseg, 1998)

Ahhoz, hogy eligazodjunk a különböző fejlesztési elképzelések, célok sűrüjében, ezek egymáshoz való viszonyát is tisztáznunk kell, kitérve arra, melyek azok, amik mindenkit és melyek azok, amik csak egyes csoportokat érintenek. Ekkor alakítjuk ki a célhierarchiát, a célpiramist, ami a részcélok közötti kapcsolatra, valamint a megvalósulásuk tervezett időrendi ütemezésére is utal.

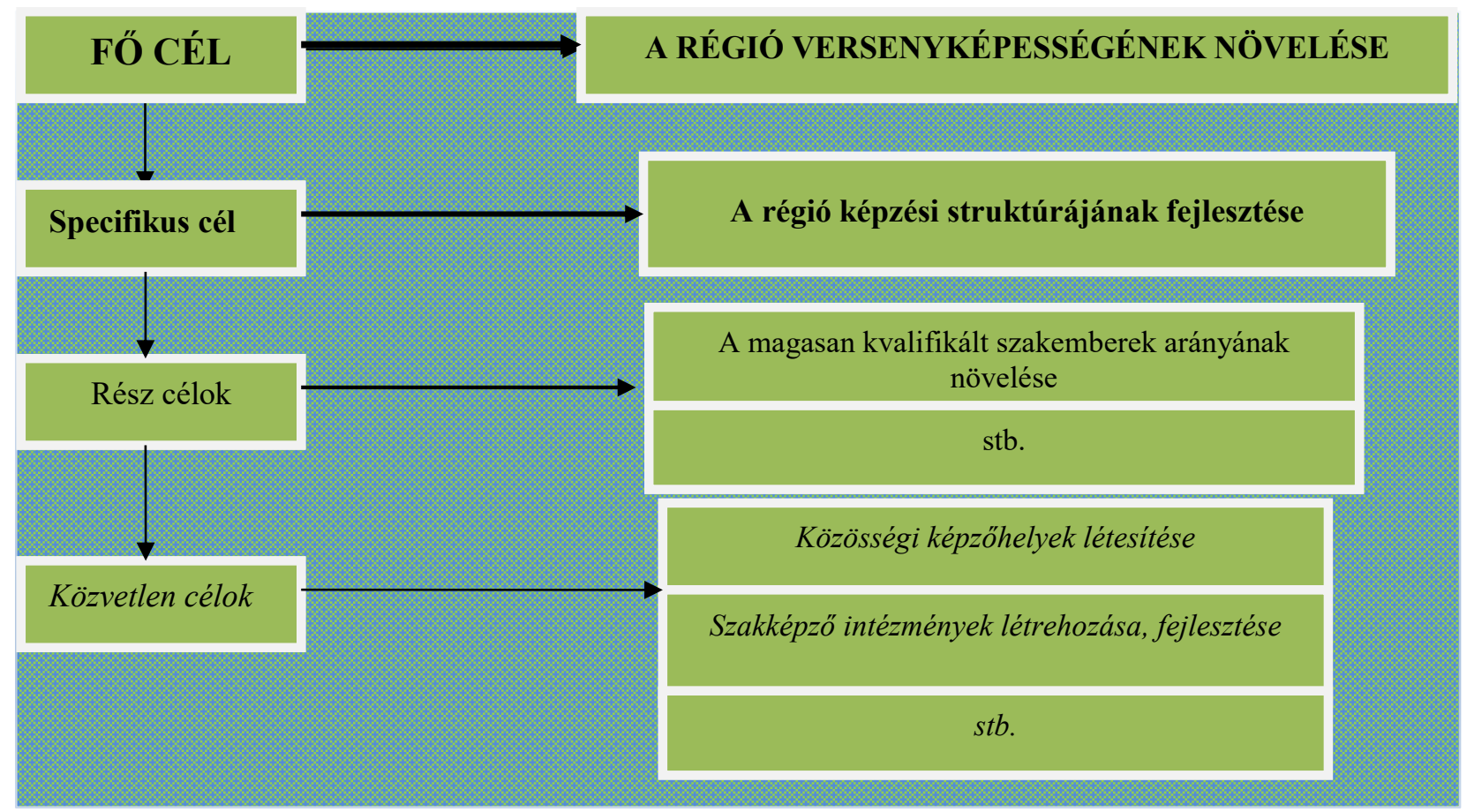

4. ábra: A célok hierarchiája a feladat alapján

Forrás: Tóth, saját szerkesztés, 2018.

A célhierarchia vázolt struktúráját tekintsük első olyan próbálkozásunknak, amely az elméleti ismeretanyag gyakorlati felhasználásának képességét méri, azaz az elvárt kompetenciáknak való megfelelés első lépcsőfokának.

Gyakran használt módszerek: brain storming módszer, collective notebook (CNB) eljárás, Rohrbach-féle 635-ös módszer, METAPLAN módszer, logikai keretmódszer, regionális veszteségtérkép, SWOT analízis, Fuzzy logika, lineáris programozás. 


\section{A fejlesztés lehetséges modelljének, forgatókönyvének kidolgozása/V. lépés/}

"A közösségi feltárást végző helyi lakosok, a kezdeményezők, a szerkesztők, a kérdezők, az értékelök stb. már maguk egy közösséget alkotnak, amelynek saját tevékenysége (projektje) maga a közösségi feltárás, és amelynek költségeire pályázhat is. Emellett a közösség mellett még számos másik is kibontakozik a tervek megvalósítása során. E közösségekkel immár önmagukon belül kell újra végigbeszélni identitásukat, feladataikat, stratégiájukat, lehetöleg bentlakásos képzés keretében. Segíthet új közösségek megalakításánál a helyi tehetségek közjóra való munkálkodása: pl. helyi lap indítása, múzeum kialakítása, nyelvórák adása stb. mindenütt közösségi megoldásokat keressünk! Természetesen a közösség nem lesz képes minden elvárásnak a saját maga által előteremtett forrásokból megfelelni, de nagyon sokat lehet és kell is tenni helyi szinten. Külső segítség-források mind tanácsok, mind anyagi eszközök formájában rendelkezésre állhatnak, de a munka elvégzéséért maga a település vállal felelösséget. A projektek tervezésénél számba kell venni, hogy melyek a megvalósításához szükséges emberi befektetések: közösségi szerveződések, tanulási, tájékozódási folyamatok beindításának szükségessége; anyagi befektetések; vállalkozási, szövetkezeti formák keresése, pályázati lehetőségek; s mindehhez milyen szakmai, szaktanácsadói, információs és szervezési háttér, közösségi álláshely/ek teremtése szükséges, stb.” (Varga-Vercseg, 1998)

Ahhoz, hogy megfelelően tudjuk strukturálni az elvégzendő feladatokat, mindent időben tudjunk elvégezni, a fejlesztés lehetséges forgatókönyvét is szükséges összeállítanunk. Az elérendő célok, az elvégzendő feladatok mind-mind hatással vannak egymásra, lényeges kérdés hogy a szükséges erőforrások mindig időben, megfelelő mennyiségben és minőségben álljanak rendelkezésre. Rendszerben kell tehát gondolkodnunk és a rendszer elemei közti összefüggéseket is ismernünk kell, csak így tudunk egy hatékony forgatókönyvet összeállítani.

Mindegyik forgatókönyv beteljesedésének vagy egyéb forgatókönyvek kidolgozásának van eshetősége, természetesen nagyságrendileg nagyobb részletezettséggel mint a példákban, de a térségek adottságai alapján célszerü a forgatókönyv típust kiválasztani és az alapján dolgozzuk ki a fejlesztési koncepciót.

Gyakran használt módszerek: brain storming módszer, collective notebook (CNB) eljárás, Rohrbach-féle 635-ös módszer, METAPLAN módszer, logikai keretmódszer, SWOT analizis, társadalmi elszámolási mátrix, LINE modell.

\section{Hatásvizsgálatok/VI. lépés/}

A hatásvizsgálatok jelentőségét sokan és sokszor elfelejtik, bár elvégzésükkel rengeteg felesleges költségtöl szabadulhatunk meg. A hatásvizsgálat feladata a programok, projektek várható következményeinek bemutatása, elemzése. Ennek segítségével megalapozottabbá válik a tervezésben a programok, kulcsprojektek elökészítési és kiválasztási folyamata.

A hatásvizsgálat segítségével:

1. Felismerjük a programok által okozott legfontosabb gazdasági, társadalmi és természeti változásokat.

2. Megvizsgáljuk, hogy a változások és hatások hogyan épülnek egymásra logikailag, kiválasztjuk a legjelentősebbeket.

3. A változásokat mérhetővé tesszük.

4. A hatásokat megfelelően értelmezzük, majd megfelelő információkat biztosítunk a társadalom tagjai számára a program várható hatásairól. 
A hatásvizsgálat összegyüjti és egységes logika szerint értelmezi a programok és projektek lehetséges hatásait (a hatások közti összefüggéseket, a hatások mögött meghúzódó okokat, feltételeket, illetve az egyes beavatkozások konzekvenciáit), valamint egyértelmüvé teszi a beavatkozási alternatívák várható előnyeit és hátrányait.

A hatásvizsgálat támogatja:

- a programok tervezését: segít egyértelmüen tisztázni, hogy az egyes beavatkozások/kal

- Mit akarunk megvalósítani?

- Mit akarunk megváltoztatni?

- Azokat milyen módon kívánjuk megvalósítani?

- Kiket fognak érinteni?

- Azokat mikor kívánjuk megvalósítani?

- A programozást: segít az egyes folyamatokban a költségek, a kockázatok megosztási döntéseinél, valamint az egyes programelemek egymásra épülését is előzetesen meghatározza.

- A végrehajtást: az intézményrendszerben előzetesen jelzi a felelősségek és költségek megoszlását, így megkönnyíti az eljárásrendek, a felelősségvállalások szabályait. Egyúttal segíti annak kijelölését, hogy a monitoring rendszer milyen folyamatokat figyeljen.

Ezért nem kerülhető meg, hogy javaslatot tegyünk a fejlesztési hatások mérésére, várható környezeti, gazdasági változások és társadalmi reakciók előrejelzésének módjaira. $\mathrm{Ne}$ a megvalósítás során derüljön ki az, hogy tévúton járunk és nem a tervezett következményei lesznek az elképzeléseinknek.

Gyakran használt módszerek: térképi ábrázolás és térinformatikai módszerek, regionális veszteségtérkép, SWOT analizis, klaszteranalizis, ECO-line modell, Socio-line modell, LINE modell, input-output megközelités, társadalmi elszámolási mátrix.

\section{Javaslatok a célokkal konform eszköz-és intézményrendszerre/VII. lépés/}

A javaslatot természetesen meghatározzák a rendelkezésre álló vagy nehezen elérhető pénzügyi erőforrások, a nem pénz jellegü eszközök és a stratégiaalkotás és megvalósítás szervezeti keretei és humánerőforrásai melyek "kovászt adnak a tervezés kenyerének."

A tervezés során arra is fókuszálnunk kell, hogy az általunk elképzelt jövőbeni célok megvalósítása milyen időtávon lehetséges, vagy egyáltalán lehetséges-e, milyen források állnak rendelkezésünkre, ezeket a forrásokat milyen módon tudjuk mobilizálni.

A területi egységhez kötődő lehetséges erőforrások, melyek alapjai lehetnek a program megvalósításnak: Emberi erőforrás; Infrastruktúra; Információ; Partnerek; Természeti erőforrások; Pénzügyi erőforrások.

A tervek sikeres realizálása szempontjából szükséges megvizsgálnunk, hogy a stratégiaalkotás és megvalósítás szervezeti keretei és humán erőforrásai elégségesek, vagy egyáltalán alkalmasak-e a várható feladatok sikeres megoldására. Amennyiben a müködtetés, pályázati aktivitás, projekt készítés és kivitelezés stb. múltbeli tapasztalatai nem nyújtanak garanciát a zökkenőmentes realizálásra, valamint a gyakorlati ismeretekből következően a jövőbeli feladatok erőforrás igényei túlmutatnak a jelenlegi kereteken, akkor megoldási alternatívákat is ki kell dolgozni. 
Gyakran használt módszerek: collective notebook (CNB) eljárás, Rohrbach-féle 635-ös módszer, METAPLAN módszer, logikai keretmódszer, Fuzzy logika, lineáris programozás, hálótervezés ${ }^{2}$.

\section{Megvalósítás /VIII. lépés/}

A megvalósítás jelen esetben azt jelenti, hogy a stratégia kivitelezése, végső formába öntése valósul meg a programok tagolásával, és projektálásával. Tehát adott területi egységre vonatkozóan, a stratégiai célrendszer megvalósulását szolgáló projektek kialakítását, kidolgozását tartalmazza, nem a tervek kivitelezését jelenti.

Gyakran használt módszerek: METAPLAN módszer, logikai keretmódszer, hálótervezés

\section{Monitoring/IX. lépés/}

A monitoring, a hatásvizsgálathoz hasonlóan a kevéssé preferált lépésekhez tartozik, és sokan csak a hibakeresést értik alatta, bár jelentősége ezen túlmutat. A tervezés során folyamatosan változó körülmények közt kell dolgozni, ami azt is jelenti, hogy a tervezés tárgya is változik, átalakul, hatások érik, ezért fontos, hogy a nem várt hatások következtében szükséges korrekciókat elvégezzük és a fejlesztési folyamatot is figyeljük a célok pontos kialakítása és elérése érdekében. (Tóth, 2008)

A tervezés lényege - ahogy már többször említésre került -, hogy rendszeresen átgondoljuk és kidolgozzuk a jövőre vonatkozó célokat, valamint meghatározzuk az elérésükhöz szükséges programokat, eszközöket, módszereket, intézkedéseket.

A terv, egyes fejlesztési célok, programok azonban annyit érnek, amennyit meg tudunk belöle valósítani. Ennek érdekében lehet szükség a korrekciók elvégzésére, alkalmazkodási, igazodási intézkedések folyamatos kidolgozására.

Gyakran használt módszerek: kérdöives megkérdezés, logikai keretmódszer, közúthálózat megfelelöségi mutató, komplex közlekedési hálózati mutató (TRANS), Hoover index, ECO-line modell, Socio-line modell, LINE modell, input-output megközelités, társadalmi elszámolási mátrix.

Az egyes folyamatlépéseknél felsorolt módszerek nem ugyanolyan mértékben segítik az adott lépés sikeres végrehajtását. Célom jelen esetben csak annyi volt, hogy felhívjam a figyelmet

\footnotetext{
${ }^{2}$ A hálótervezés módszere minden olyan területen alkalmazható, ahol az elvégzendő feladatok kapcsán jelentkező részfeladatok egy kezdö és egy befejezö tevékenységgel (eseménnyel) meghatározhatók. Alkalmazásának további feltételei az alábbiak szerint foglalhatók össze:

- a részfeladatok logikai összefüggésben vannak egymással,

- $\quad$ sorrendiségük egyértelmüen meghatározható,

- a részfeladatok halmaza irányított részekből áll, és nem tartalmaz ciklusokat.
}

A módszer alkalmazása lehetővé teszi a munkafolyamatra vonatkozó számszerüsíthető adatok, az idő-, költség- és kapacitásigény elemzését és optimalizálását.

A hálótervezés részei az alábbiak:

- Logikai háló (hálószerkesztés)

- Időháló (időtervezés)

- Költségtervezés

- Erőforrás allokáció (kapacitástervezés)

A fentiekben említett részek önálló egységként is kezelhetők, de egymásra épülve rendszert alkotnak. 
arra, milyen széles a felsorolt alkalmazható módszerek tárháza, mivel tapasztalataim alapján, a területi tervezéskor gyakorlati alkalmazásuk hazánkban, csak esetlegesnek nevezhetö.

Bakos (2017) megállapításával egyetértve egy sikeres településnek szüksége van olyan alulról jövő kezdeményezésekre és példaértékü önszerveződő közösségekre, akik hozzá tudnak járulni a helyi fejlesztésekhez. A helyi közösségekben meglátása szerint kódolva van az önfenntartás bizonyos foka, amely a megfelelö támogató közeg és a helyi gazdaságfejlesztésben olyan gyakran emlegetett „helyi hősök” közösséget aktivizáló munkája révén felébreszthető és életképesen müködtethető.

Mint ahogy azt a sajnos nem rég elhunyt G Fekete Éva is megfogalmazta, a sikeres önkormányzatok a közmegelégedettségére müködtetik intézményeiket, segítik a foglalkoztatás megoldását, tiszta és egészséges környezetet teremtenek, náluk a helyi érdekek megfogalmazhatók és azokat meg is védik. (G. Fekete, 2011) Ha van nyilvánvaló helyi érdek, akkor a döntéshozó is jobban tudja mi a saját feladata! Mindenkire szükség van, aki a közösség erősítéséért tehet (pl.: civilek, egyházak, vállalatok stb.)

\section{Következtetések, javaslatok}

A közösségi tervezés, amelynek során az érintettek megismerik egymás álláspontjait, érdekeit, majd a közös munka során törekszenek a konszenzusos megoldások megtalálására, jóval alkalmasabb a nyertes-nyertes kiutak feltárására, mint a külső tervező által kitalált és diktált sémák. A közösségi tervezés hosszú távú, közvetett társadalmi hozadékai tipikusan a következők lehetnek:

\section{Erösödik a társadalmi töke, a közösség megtartó ereje}

A társadalmi tőke a közösséggel való azonosulás fokára utal. A helyi részvételen alapuló tervezés során a közösség tagjai sokoldalú interakcióba kerülnek egymással. Különbözö hátterü emberek, illetve csoportjaik ismerik meg egymás álláspontját, értékeit, érdekeit. Gyarapszik a közösségen belüli ismeretségi háló, potenciális együttmüködési lehetőségek alakulnak ki, s növekszik a közösség tagjainak társadalmi tőkéje. Természetesen az erős közösségek népességmegtartó ereje is nagyobb. A közösség tagjai abban motiváltak, hogy az életüket eredeti lakhelyükön rendezzék be.

\section{Növekszik az emberek jóléte, javul egészségi állapotuk}

Azokban a közösségekben, ahol jobb az egyének önértékelése, erősebb a társadalmi tőkéje, magasabb a társadalmi kohézió szintje, ott ritkábbak az önkárosító magatartásformák, jobb a stressztürő képesség, és alapvetően kedvezőbbek a népegészségügyi mutatók. Hazai kutatások is beszámolnak arról, hogy a társadalmi tőke mutatói, azaz a másokba vetett bizalom, kölcsönösség, a polgári szervezetekben való tagság, a kollektív hatékonyság, a vallásos élet és a versengő magatartás kölcsönös összefüggésben vannak a középkorúak mortalitásával. A közösséghez tartozás tehát kimutathatóan növeli a közösség tagjainak jól-létét, közvetve javítja egészségi állapotát.

\section{Aktivizálódik a közösség, erösödik érdekérvényesítö képessége, fejlödési potenciálja}

A közösségi kapcsolatok számának gyarapodásával és a közösségi összetartozás élményének megélésével jelentős mértékben megnő a csoporton belüli összetartás. Az együttmüködésben elért kis sikerekkel a közösség tagjai tudatára ébrednek, hogy képesek saját kezükbe venni sorsuk alakítását, és összefogva, együttmüködésben komoly lépéseket tehetnek. A társadalmi 
tőkét lassan világszerte a gazdasági fejlődés létfontosságú összetevőjeként tartják számon. A vidékfejlesztés tanulmányozóinak kutatási eredményei azt mutatják, hogy egy helyi egyesületekből álló hatékony hálózat legalább olyan fontos lehet a növekedés szempontjából, mint a fizikai beruházások, a megfelelö technológia.

A nehézségek leküzdését segíti az intézményesített beavatkozás, amely akár közösségfejlesztés, akár közösségi részvételen alapuló tervezés formájában szisztematikusan adja át a megfelelö tudást, információt, készségeket a közösség számára.

\section{Nö a közösség stabilitása, egyéni szinten javul az esélyegyenlöség}

Fontos, hogy a különböző társadalmi csoportok között is létrejöjjenek kapcsolatok, amelyek egymástól elkülönülö, távolabbi embereket kötnek össze. A közösségi tervezés segít abban, hogy eltérö hatalommal rendelkező személyek, csoportok közötti kapcsolatok is kialakuljanak.

\section{Erősödik a térségi identitás}

A közös gondolkodása során a különböző hátterü csoportok egyrészt megismerik egymás nézőpontját, értékeit, másrészt a tervezés egyes kérdéseiben konszenzusos javaslatok születnek a térség jövőjével kapcsolatban. Mindez erősíti a helyhez kötődő, közösségi gondolkodást, a térségi identitást, amely az egyének életében, értékválasztásaiban is döntő.

\section{Köszönetnyilvánítás}

A mü a KÖFOP-2.1.2-VEKOP-15-2016-00001 azonosítószámú, „A jó kormányzást megalapozó közszolgálat-fejlesztés" elnevezésü kiemelt projekt keretében, a Nemzeti Közszolgálati Egyetem felkérésére készült.

\section{Irodalomjegyzék}

1. Bakos I. (2017): A lokális élelmiszerek fogyasztói megítélése és innovatív értékesítési lehetősége. A Falu, XXXII. évf. 2017. nyár. 5-14 pp.

2. Bakos I. M. - Bálint Cs. (2015): Egészséges (?) Hollókő. In: Nagyné M. M. (szerk.): Acta Regionis Rurum 9. kötet: Faluszemináriumi kutatások - Hollókő. Szent István Egyetemi Kiadó, 92-103.

3. Bruder W.- Ellwein, T. (1979): Raumordnung und staatliche Steuerungsfähigkeit. Politische Vierteljahresschrift, 10. Sonderheft

4. Faragó L. (2009): Habilitációs tézisek, Győr, 2009.

5. G. Fekete É. (2011): A Nemzeti Vidékstratégia (2014-2020) hangsúlyai a vidéki népesség megélhetése, jövője szemszögéből előadás: https://mtvsz.hu/dynamic/g_fekete_eva_videkstrat_a_videki_nepesseg_megelhetese jovoje_szemszogebol_2011_03_10.pdf

6. Gerencsér I., Tóth T. (2017) „Lesz ez még így sem” avagy a településvezetők szerepe helyi fejlesztésekben két település példáján keresztül STUDIA MUNDI ECONOMICA 4:(4) pp. 2-11.

7. Goda P., Káposzta J, Péli L. (2013): Case study on spider-net enthrophy investigation in rural areas REVIEW ON AGRICULTURE AND RURAL DEVELOPMENT 2:(1) pp. 296-300.

8. Goda P., Kassai Zs. (2011): A 2004-2010 közötti gazdaság - és regionális fejlesztő operatív programok összehasonlító kistérségi vizsgálata. In: Gazdaság és Társadalom 2011/2, pp. 93-110 DOI: 10.21637/GT.2011.2.07 
9. Goda P., Tóth T. (2013): Pókháló- entrópia, mint új rendszervizsgálati megközelítés a területi elemzésekben. In: Területi Statisztika, 53 (2) pp. 169-189. DOI: 10.15196/TS560101

10. Horváth E. (2013): Kicsik között a legkisebbek - a törpefalvak sikerességének kulcstényezői, doktori disszertáció, Széchényi István Egyetem, Regionális- és Gazdaságtudományi Doktori Iskola, Győr p.205 DOI: 10.14232/phd.3950

11. Káposzta J.- Ritter K.- Kassai Zs. (2015): Hungarikumok területi jelentőségének vizsgálata, különös tekintettel a pálinkára. In: Tér és Társadalom 29 (4), pp. 139-153. DOI: 10.17649/TET.29.4.2707

12. Káposzta J. (2001): Regionális gazdaságtan, Gödöllő DOI: 10.18531/Studia.Mundi.2016.03.01.52-61

13. Káposzta J., Kollár K., Péli L. (2012): The examination of major economic coherences in the Hungarian least-developed micro-regions REVIEW ON AGRICULTURE AND RURAL DEVELOPMENT 2012:(1) pp. 309-313.

14. Káposzta, J.-Nagy, H. (2003): The inherence of the development of the spatialstructure in Hungary. Conference lecture. 25th IAAE Conference, South Africa, Durban

15. Kruse, H. (1990): Reform durch Regionalisierung. Eine politische Antwort auf die Umstrukturierung der Wirtschaft. Campus, Frankfurt am Main.

16. Nagyné Molnár M. (2013): Factors of successincase of local society. In: Deturope: Central european journal of tourism and regional development, 5 (3) pp. 63-70. DOI: $10.1057 / 9780230247017$ _4

17. Oláh I. (2017) 1000 fö alatti települések vizsgálata Magyarországon 167 p. Szent István Egyetem Enyedi György Regionális Tudományok Doktori Iskola

18. Piskóti, I. (2000): A régió és településmarketing kockázatai - a célrendszer és a stratégiai döntési dimenziók.

19. Rechnitzer J. Smahó M. ( 2011) Területi politika, Akadémiai Kiadó, 2011

20. Ritter K. - Nagy H. - Tóth T. (2013): Hátrányos helyzetü vidéki térségek és helyi fejlesztési lehetőségeik egy Észak-magyarországi példán keresztül. pp. 224-242. In: Lukovics M. - Savanya P. (szerk.) (2013): Új hangsúlyok a területi fejlödésben. Szeged: JATE Press

21. Szaló, P. (2010): Területfejlesztési füzetek 1. : segédlet a közösségi tervezéshez, Budapest 2010.93 p.

22. Szilágyi T., Boldizsár G.: (2016) A biztonságos vidék, mint az állam létfeltétele PRO SCIENTIA RURALIS 1:(4) pp. 24-34.

23. Tóth T. (2008): Területi tervezés és programozás, Egyetemi Kiadó SzIE Gödöllő Gazdaság- és Társadalomtudományi Kar, Gödöllő

24. Tóth T., Oláh I. (2012): A közösségi tervezés elméleti és gyakorlati alapjai In: Farkas Attila, Kollár Csaba, Laurinyecz Ágnes (szerk.) A filozófia párbeszéde a tudományokkal: A 70 éves Tóth Tamás professzor köszöntése. 447 p. Budapest: Protokollár Tanácsadó Iroda, 2012. pp. 358-370.

25. Varga, A. T., - Vercseg, I. (1998): Közösségfejlesztés. Magyar Müvelödési Intézet, Budapest, 6. 294 p. 